\title{
Seroprevalence and risk factors associated with infection by Neospora caninum of dairy cattle in the state of Alagoas, Brazil ${ }^{1}$
}

\author{
Maria E. Sousa ${ }^{2}$, Wagnner J.N. Porto ${ }^{3}$, Pedro P.F. Albuquerque ${ }^{4}$, Orestes L. Souza Neto ${ }^{4}$, \\ Eduardo B. Faria ${ }^{4}$, José W. Pinheiro Júnior ${ }^{5}$ and Rinaldo A. Mota ${ }^{6 *}$
}

\begin{abstract}
Souza M.E., Porto W.J.N., Albuquerque P.P.F., Souza Neto O.L., Faria E.B., Pinheiro Júnior J.W. \& Mota R.A. 2012. Seroprevalence and risk factors associated with infection by Neospora caninum of dairy cattle in the state of Alagoas, Brazil. Pesquisa Veterinária Brasileira 32(10):1009-1013. Departamento de Medicina Veterinária, Universidade Federal Rural de Pernambuco, Rua Dom Manoel de Medeiros s/n, Recife, PE 52171900, Brazil. E-mail: rinaldo.mota@hotmail.com

The objective of this study was to investigate the prevalence of anti-Neospora caninum antibodies in cattle from milk producing farms of the microregion of Batalha, state of Alagoas, Brazil, as well as to identify the risk factors associated with the infection. Blood samples were collected from 1,004 cattle of 17 farms for the serological investigation regarding the presence of anti- $N$. caninum antibodies by the Indirect Immunofluorescence Reaction Technique (IMRT). From the total amount of samples analyzed, 77/1,004 (7.67\%) were positive and $927 / 1,004(92.33 \%)$ were negative. The logistical regression identified that cattle from farms without consortium breeding have an infection risk 6.33 ( $\mathrm{p}<0.001$; C.I. 2.89-13.10) times higher than cattle from farms with that type of breeding. Cattle from farms where the aborted fetuses are not adequately buried have an infection risk 3.04 ( $p<0.001$; C.I. 1.64-5.63) times higher than cattle from farms with adequate destination of these fetuses. Infection by $N$. caninum occurs in cattle of the investigated region. The factors identified in our study can be used as risk indicators, so that control measures could be implemented to avoid infection by $N$. caninum in the herds of this region.
\end{abstract}

INDEX TERMS: Neospora caninum, neosporosis, bovine, epidemiology.

RESUMO.- [Soroprevalência e fatores de risco associados à infecção por Neospora caninum em bovinos leiteiros no Estado de Alagoas.] Objetivou-se com este estudo investigar a prevalência de anticorpos anti-Neospora caninum em bovinos procedentes de propriedades leiteiras da microrregião Batalha, Estado de Alagoas, Brasil, além de identificar os fatores de risco associados à infecção. Foram coletadas amostras

\footnotetext{
${ }^{1}$ Received on June 8, 2012.

Accepted for publication July 4, 2012.

${ }^{2}$ Centro de Estudos Superiores de Maceió (Cesmac), Rodov. Divaldo Suruagy s/n, Marechal Deodoro, AL 57160-000, Brazil.

${ }^{3}$ Unidade Educacional de Viçosa, Campus Arapiraca, Universidade Federal de Alagoas, Fazenda São Luís s/n, Zona Rural, Viçosa, AL 57700-000.

${ }^{4}$ Mestrando do Programa de Pós Graduação em Ciência Animal Tropical, Universidade Federal Rural de Pernambuco (UFRPE), Av. Dom Manoel de Medeiros s/n, Dois Irmãos, Recife, PE 52171-900, Brazil.

${ }^{5}$ Unidade Acadêmica de Garanhuns, UFRPE, Av. Bom Pastor s/n, Boa Vista, Garanhuns, PE 55292-270, Brazil.

${ }^{6}$ Departamento de Medicina Veterinária, UFRPE, Dois Irmãos, Recife, PE. *Corresponding author: rinaldo.mota@hotmail.com
}

de sangue de 1004 bovinos procedentes de 17 propriedades para investigação sorológica quanto à presença de anticorpos anti- $N$. caninum através do teste de Reação de Imunofluorescência Indireta (RIFI). Do total das amostras analisadas, $77 / 1004(7,67 \%)$ foram positivas e $927 / 1004(92,33 \%)$ foram negativas. A regressão logística identificou que animais de propriedades sem criação consorciada têm risco 6,33 $(\mathrm{p}<0,001$; I.C. 2,89-13,10) vezes maior de infecção do que animais de propriedades onde ocorre esse tipo de criação. Animais de propriedades onde os fetos abortados não são adequadamente enterrados têm risco 3,04 (p<0,001; I.C. 1,645,63 ) vezes maior de infecção do que animais de propriedades onde é feito o destino adequado dos mesmos. A infecção por $N$. caninum ocorre em bovinos na região estudada. Os fatores identificados neste estudo podem servir como indicadores de risco para que sejam implantadas medidas de controle para evitar a infecção por N. caninum nos rebanhos dessa região.

TERMOS DE INDEXAÇÃO: Neospora caninum, neosporose, bovinos, epidemiologia. 


\section{INTRODUCTION}

Neospora caninum is an obligatory intracellular parasite which causes neosporosis, known as the most important cause of abortions in cattle worldwide (Dubey 2003), with reabsorption or fetal mummification, or the birth of healthy calves though chronically infected (Dubey \& Schares 2006).

The infection is widely disseminated in all continents (Andreotti et al. 2003). In Brazil, serological studies revealed the presence of antibodies in Bahia (14.9\% - Gondim et al. 1999), São Paulo (15.57\% - Hasegawa et al. 2004), Goias (30.4\% - Melo et al. 2006), Minas Gerais (29\% - Ragozo et al. 2003), Rio de Janeiro (25.74-20.38\% - Munhoz et al. 2006), Rio Grande do Sul (17.8\% - Corbellini et al. 2006), Mato Grosso do Sul (9.17\% - Melo et al. 2008), Pernambuco (31.7\% - Silva et al. 2008), Espirito Santo (17.5\% - Fanti et al. 2009), and Mato Grosso (53.5\% - Benetti et al. 2009).

Risk factors reported in papers from around the world have been associated with infection by $N$. caninum in cattle, such as: feed for adult cattle with moist corn silage during the Summer (OR 6.58), presence of birds (OR 4.6-10.42) (Bartels et al. 1999), calf feed with "pool" of colostrum (OR 2.07) (Corbellini 2005), presence of dogs (OR 4.2) on the farms, size of the farms (OR 0.90) (Corbellini et al. 2006), and age (Fanti et al. 2009).

The importance of investigating the herds regarding neosporosis is justified by the great economic losses reported worldwide (Hernández et al. 2001), and also by the still limited knowledge of the prevalence of the agent in some states of Brazil. Thus, the objective of this study was to investigate the prevalence of anti- $N$. caninum antibodies in cattle of milk producing farms in the microregion of Batalha, state of Alagoas, Brazil, as well as to identify the risk factors associated with the infection.

\section{MATERIALS AND METHODS}

The state of Alagoas is located in the Central-Eastern portion of the Northeast of Brazil, between the parallels $8^{\circ} 48^{\prime} 12^{\prime \prime}$ and $10^{\circ} 30^{\prime} 12^{\prime \prime}$ of the Southern latitude and the meridians $35^{\circ} 09^{\prime} 36^{\prime \prime}$ and $38^{\circ} 13^{\prime} 54^{\prime \prime}$ of the Western longitude. It is divided into three mesoregions: Alagoan Eastern Region, Alagoan Agreste Region and the Alagoan Sertao Region (UFAL-GEM 1994, Assis et al. 2007).

The microregion of Batalha (Milk producing basin), part of the Mesoregion of the Alagoan Sertao Region (Fig.1), is composed of the municipalities of Batalha, Belo Monte, Jacare dos Homens, Jaramataia, Major Izidoro, Monteiropolis, Olho D’Agua das Flores and Olivença (IBGE 2005).

To compose the sample for the prevalence study, a total of 96,034 cattle heads were considered, as well as an expected prevalence of $30 \%$, obtained through the average of articles published in Brazil, with a confidence level of $95 \%$ and statistical error of 5\% (Thrusfield 2004). Thus, the determined minimum sample was of 323 animals. However, it was decided that the study would involve 1,004 samples obtained from 17 farms of 8 municipalities. The choice of the farms and the animals was carried out according to the accessibility and availability of the producers. Blood samples were also collected from the dogs present on the farms at the moment of collection from the cattle.

For the anti- $N$. caninum antibodies study, the Indirect Immunofluorecence Reaction Technique (IMRT) was used. The serum samples were submitted to selection, having as the cut point the dilution of 1:200 (for cattle) and of 1:50 (for dogs) in blades previously sensibilized with tachyzoites of $N$. caninum cultivated in Vero cells. The anti-IgG-bovine and anti-IgG-canine antibodies conjugated with the isotiocianate of fluoresceine of the Sigma-Chemical brand were used as secondary antibodies. Previously known standard, positive and negative serums were included in all blades (Dubey 1988).

The reactions were considered positive when the tachyzoites presented total periferic fluorecence (Dubey \& Lindsay 1996). The positive serums in the dilution 1:200 (cattle) and 1:50 (dogs), were submitted to sequential dilutions to determine the title of the antibodies.

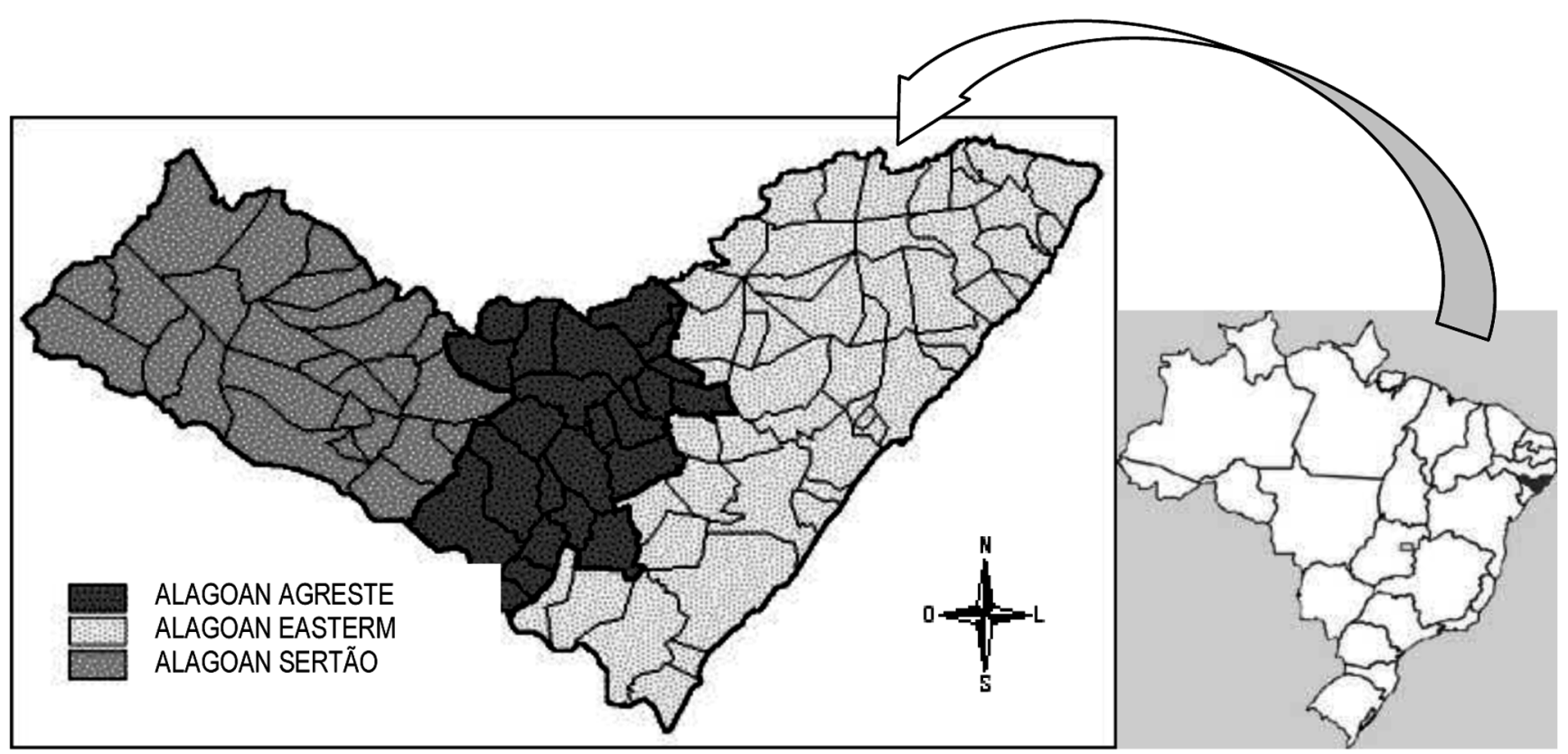

Fig.1. Mesoregions of the state of Alagoas. (Source: http://www.zonasuldemaceio.com.br/alagoas/imagens/250px-Alagoas_MesoMicroMunicip.svg.png). 
For the study of risk factors, investigative questionnaires were applied with objective questions about the general characteristics of the farm and of the herd, and the nutritional, reproductive and hygienic-sanitary handling.

To identify the risk factors associated with infection by $N$. caninum, an univariate analysis of the interest variables was carried out using the Pearson's chi-square test. Later, a multivariate analysis using the logistical regression model was carried out, considering as a dependent variable the serological status of the animal (positive or negative) for $N$. caninum. All variables that presented a value of $p<0.10$ in the univariate analysis were included in this model. The significance level adopted was 0.05 . To execute the statistical calculations, the program SPSS for Windows, version 180 - Statistical Package for Social Science, was used.

\section{RESULTS}

The results of this study reveal that from the 1,004 analyzed samples, 77 (7.67\%) were positive and 927 (92.33\%) negative. From the 17 farms investigated, 15 had at least one cow that was positive (Table 1).

In the univariate analysis, the variables of sex, destination of aborted fetuses, consortium breeding with other species, presence of forested areas in the surroundings of the farms, presence of domestic dogs and wild animals, water used to wash the stables and the origin of the drinking water for the cattle, presented a value of $P<0.05$, and therefore were selected for the multivariate analysis (Table 2 ). From these variables, only the adequate destination of aborted fetuses $(\mathrm{OR}=3.04)$ and non-consortium breeding $(\mathrm{OR}=6.33)$ were considered risk factors associated with infection by Neospora caninum in the herds studied (Table 3).

With respect to the sex variable, there was a greater number of seropositives amongst females (8.2\%) when compared with males $(0.0 \%)$.

The cattle of dairy farms where there was no consortium breeding with other species, presented a risk about 6.33 times greater $(\mathrm{OR}=6.33$; $\mathrm{P} 0.001)$ of infection by $\mathrm{N} . \mathrm{ca}$ ninum than cattle of farms with consortium breeding (Table 3).

Table 1. Distribution of samples tested for anti-Neospora caninum antibodies in the municipalities and properties of the microregion of Batalha, state of Alagoas, Brazil

\begin{tabular}{cccc}
\hline Property & Municipality & $\begin{array}{c}\text { № of samples } \\
\text { tested }\end{array}$ & $\begin{array}{c}\text { № positive } \\
\text { samples }\end{array}$ \\
\hline Farm 1 & Batalha & 53 & 1 \\
Farm 2 & Batalha & 47 & 7 \\
Farm 3 & Major Izidoro & 51 & 2 \\
Farm 4 & Major Izidoro & 28 & 7 \\
Farm 5 & Olivença & 67 & 1 \\
Farm 6 & Belo Monte & 125 & 7 \\
Farm 7 & Monteirópolis & 89 & 10 \\
Farm 8 & Batalha & 57 & 3 \\
Farm 9 & Jacaré dos Homens & 54 & 8 \\
Farm 10 & Jacaré dos Homens & 69 & 0 \\
Farm 11 & Olho D'água das Flores & 96 & 3 \\
Farm 12 & Olho D'água das Flores & 84 & 12 \\
Farm 13 & Jaramataia & 62 & 13 \\
Farm 14 & Jaramataia & 11 & 1 \\
Farm 15 & Jaramataia & 26 & 1 \\
Farm 16 & Jaramataia & 13 & 0 \\
Farm 17 & Major Izidoro & 72 & 1 \\
TOTAL & & 1,004 & 77
\end{tabular}

Table 2. Univariate analysis for risk factors associated or not to infection by Neospora caninum in bovines of the state of Alagoas, Brazil

\begin{tabular}{|c|c|c|c|c|}
\hline Variates & $\mathrm{N}$ & $\frac{\text { N. caninum }}{\text { RIFI (\%) }}$ & $\frac{\text { Univariate analysis }}{\text { OR (CI 95\%) }}$ & $P$ \\
\hline \multicolumn{5}{|l|}{ Sex } \\
\hline Female & 944 & $77(8,2 \%)$ & & $0,011^{*}$ \\
\hline Male & 60 & $0(0,0 \%)$ & - & \\
\hline \multicolumn{5}{|c|}{ Destination of placentas } \\
\hline Did not have abortion & 26 & $1(3,8 \%)$ & 1,0 & 0,817 \\
\hline Bary & 373 & $27(7,2 \%)$ & $1,95(0,25-4,96)$ & \\
\hline Cremate & 57 & $3(5,3 \%)$ & $1,39(0,14-14,02)$ & \\
\hline Remains exposed & 548 & $46(8,4 \%)$ & $0,30-17,29)$ & \\
\hline \multicolumn{5}{|l|}{ Consortium breeding } \\
\hline Yes & 205 & $3(1,5 \%)$ & 1,0 & $<0,001^{*}$ \\
\hline No & 799 & $74(9,3 \%)$ & $6,87(2,14-22$ & \\
\hline \multicolumn{5}{|c|}{ Slaughterhouse in the surrounding area of the farm } \\
\hline Yes & 401 & $21(5,2 \%)$ & 1,0 & $0,018^{*}$ \\
\hline No & 603 & $56(9,3 \%)$ & $1,85(1,10-3,11)$ & \\
\hline \multicolumn{5}{|c|}{ Origino of the drinking water for the cattle } \\
\hline Public & 288 & $12(4,2 \%)$ & 1,0 & $<0,001^{*}$ \\
\hline Natural source & 146 & $25(17,1 \%)$ & $4,75(2,31-9,77)$ & \\
\hline Dam & 89 & $10(11,2 \%)$ & $2,91(1,21-6,98)$ & \\
\hline More than one source & 481 & $30(6,2 \%)$ & $1,53(0,77-3,04)$ & \\
\hline \multicolumn{5}{|c|}{ Residual water used to wash the stables spreads through the corrals } \\
\hline Yes & 302 & $16(5,3 \%)$ & 1,0 & $0,001^{*}$ \\
\hline No & 343 & $18(5,2 \%)$ & $0,99(0,49-1,98)$ & \\
\hline It does not wash & 359 & $43(12,0 \%)$ & $2,43(1,34-4,41)$ & \\
\hline \multicolumn{5}{|c|}{ Presence of wild animals } \\
\hline No & 80 & $1(1,3 \%)$ & 1,0 & $<0,001^{*}$ \\
\hline Yes & 924 & $76(8,2 \%)$ & $5,92(2,37-14,81)$ & \\
\hline \multicolumn{5}{|c|}{ Presence of domestic dogs } \\
\hline No & 275 & $5(1,8 \%)$ & 1,0 & $<0,001^{*}$ \\
\hline Yes & 729 & $72(9,9 \%)$ & $6,49(2,57-16,36)$ & \\
\hline \multicolumn{5}{|c|}{ Aborted fetuses are adequately buried } \\
\hline Yes & 298 & $13(4,4 \%)$ & 1,0 & $0,011 *$ \\
\hline No & 706 & $64(9,1 \%)$ & $2,18(1,18-4,03)$ & \\
\hline
\end{tabular}

The animals are serologically or pathologically tested against the most common aborting agents

$\begin{array}{lllcc}\text { Yes } & 583 & 37(6,3 \%) & 1,0 & 0,094 \\ \text { No } & 319 & 30(9,4 \%) & 1,53(0,93-2,53) & \end{array}$

Base $=1,004$ cattle. $\mathrm{N}=$ Total number of animals for each variable; RIFI = Reaction of Indirect Imunofluorescence; $\mathrm{OR}=$ odds ratio; $\mathrm{CI}=$ Confidence Interval; * statistically significant.

Table 3. Multivariate analysis for risk factors associated or not to infection by Neospora caninum in cattle of the microregion of Batalha, state of Alagoas, Brazil

\begin{tabular}{lccc}
\hline \multicolumn{1}{c}{ Independent Variable } & OR & CI 95\% & $\mathrm{p}$ \\
\hline $\begin{array}{l}\text { Non-consortium breeding } \\
\begin{array}{l}\text { Aborted fetuses inadequately } \\
\text { buried }\end{array}\end{array}$ & 6,33 & $2,89-13,10$ & $<0,001$ \\
\hline & 3,04 & $1,64-5,63$ & $<0,001$ \\
\hline
\end{tabular}

$\overline{\mathrm{OR}}=$ Odds ratio; $\mathrm{CI}=$ Confidence Interval $95 \%$.

The cattle that lived on dairy farms where the destination of aborted fetuses was not adequate also had a 3.04 times greater chance (OR=3.04; $P$ 0.001) of infection by $N$. caninum than cattle from farms where the aborted fetuses were incinerated or buried (Table 3).

\section{DISCUSSION}

The results of this study showed a frequency considered low when compared with results obtained in other studies carried out in other states of Brazil: 17.5\% in Espirito San- 
to (Fanti et al. 2009), 30.4\% in Goiás (Melo et al. 2006), $31.7 \%$ in Pernambuco (Silva et al. 2008), 33.0\% in Parana (Locatelli-Dittrichi et al. 2008), 50.74\% in Maranhão (Teixeira et al. 2010), 53.54\% in Mato Grosso (Benetti 2006), and $91.2 \%$ in Minas Gerais (Guedes et al. 2008).

The fact that there was a greater frequency of cattle that were seropositive amongst the females could be explained by the fact that the research study was carried out on milk producing dairy cattle herds which are predominantly females. However, in this study, as well as in the study of Teixeira et al. (2010), there was no significant association for this variable.

The high risk observed in this study for non-consorted cattle breeding with other species can be attributed to a higher concentration of cattle on the farms that breed this species exclusively, and also to the possibility of these animals having been introduced into the herd already seropositive for Neospora caninum, as previously reported by Fortunato (2010). Although the "animal density" variable was not investigated in this study, it is widely known that the number of animals in the herds is directly related to prevalence of infection (Barling et al. 2001). Dubey et al. (2007) also reported that normally, in these situations, more concentrates are used for the animal feed, and that the storing locations where this type of feed is kept attracts rodents which are potential prey for the definitive hosts of N. caninum (Gondim 2006).

Not giving adequate destination for aborted fetuses was also a confirmed risk factor in the multivariate analysis. This finding is very important epidemiologically, since dogs or wild canids can have access to infected tissues exposed in the surrounding fields of farms, increasing the chances of these definitive hosts to become infected (Dijkstra et al. 2001, Cunha-Filho et al. 2008). In one of the studied farms which presented cattle that were seropositive for $N$. caninum, two dogs were identified as being positive from the existent nine. According to the investigation questionnaire applied on this farm, the dogs had access to the corrals where the cattle were handled and probably where the fetuses were aborted, resulting in inadequate exposure of the cattle to the dogs. These results reinforce the necessity to destroy the aborted fetuses on the farm, to reduce the infection risk of canids and the prevalence of infection of the cattle. About this specific aspect Cunha-Filho et al. (2008) also observed that the adequate destination of placentas and carcasses on farms with neosporosis was considered a protecting factor for dogs. Fernandes et al. (2004) also reported that in rural areas, dogs can get infected more easily when they have access to carcasses, aborted fetuses and rests of placentas.

The greater frequency of seropositive animals in farms where they were not serologically or pathologically tested for the more common agents of abortion constitutes an important piece of data which indicates the necessity of qualified technical assistance in the efforts to avoid maintenance of the agent in the herds (Silva et al. 2008).

The farms that did not have forests near by or in the surrounding areas, presented a higher frequency of seropositive animals, even without having statistical significan- ce for this variable, indicating the importance of domestic definitive hosts on these farms (Santos et al. 2009).

The greater prevalence of infection by $N$. caninum in cattle has been related to the presence of dogs and wild animals on the farms. In spite of the fact that this study did not find any significant statistical association in the multivariate analysis for these variables, the frequency of seropositive cattle was considerably higher in the farms where these animals were present, than in those where the presence of these animals was not reported. A similar result was also observed by Santos et al. (2009) who studied the frequency of anti- $N$. caninum antibodies in cattle in Minas Gerais, Brazil. On the other hand, Schares et al. (2004), Corbellini (2005) and Corbellini et al. (2006) found significant association between seropositivity and the cited variables, reinforcing the importance of the control of these animals on the farms to avoid horizontal transmission in the herd.

In the interviews, the presence of dogs or people from farms or neighboring communities, who frequented the facilities of the researched farms - even without dogs - was reported. Based on this fact, it is important to consider the possibility of the occurrence of seropositive cattle, even on farms without seropositive dogs.

\section{CONCLUSIONS}

Infection by Neospora caninum occurs in cattle of the studied region.

The factors identified in this study could be used as risk indicators for the implementation of control measures to avoid infection by $N$. caninum in the cattle herds of this region.

\section{REFERENCES}

Andreotti R., Locatelli-Dittrich R., Soccol T.V. \& Paiva F. 2003. Diagnóstico e Controle da Neosporose em Bovinos. Embrapa Gado de Corte, Campo Grande, MS, 51p. (ISSN 1517-3747)

Assis J.S., Alves A.L. \& Nascimento M.C. 2007. Atlas Escolar Alagoas: espaço geohistórico e cultural. Grafset, João Pessoa.. 208p.

Barling K.S., McNeill J.W., Paschal J.C., McCollum III F.T., Craig T.M., Adams L.G. \& Thompson J.A. 2001. Ranch-management factors associated with antibody seropositivity for Neospora caninum in consignments of beef calves in Texas, USA. Prev. Vet. Med. 52:53-61.

Bartels C.J.M., Wouda W. \& Schukken Y.H. 1999. Risk factors for Neospora caninum- associated abortion storms in dairy herds in the Netherlands (1995 to 1997). Theriogenology 52:247-257.

Benetti A.H. 2006. Pesquisa de anticorpos anti-Neospora caninum em bovinos leiteiros da região sudoeste do estado de Mato Grosso. Tese de Doutorado, Faculdade de Ciências Agrárias e Veterinárias, Campus de Jaboticabal, Universidade Estadual Paulista, Jaboticabal, SP. 70p.

Benetti A.H., Schein F.B., Santos T.R., Toniollo G.H., Costa A.J., Mineo J.R., Lobato J., Silva D.A.O. \& Gennari S.M. 2009. Pesquisa de anticorpos anti- Neospora caninum em bovinos leiteiros, cães e trabalhadores rurais da região Sudoeste do Estado de Mato Grosso. Revta Bras. Parasitol. Vet. 18:29-33.

Corbellini L.G. 2005. Neosporose bovina: estudo de fatores de risco em 60 propriedades leiteiras no estado do Rio Grande do Sul e levantamento de causas de aborto bovino com ênfase em Neospora caninum. Acta Scientiae Veterinariae 33:231-232.

Corbellini L.G., Smith D.R., Pescador C.A., Schmitz M., Correa A., Steffen D.J. \& Driemeier D. 2006. Herd-level risk factors for Neospora caninum seroprevalence in dairy farms in southern Brazil. Prev. Vet. Med. 74:130-141. 
Cunha Filho N.A., Lucas A.S., Pappen F.G., Ragozo A.M.A., Gennari S.M., Junior T.L. \& Farias N.A.R. 2008. Fatores de risco e prevalência de anticorpos anti-Neospora caninum em cães urbanos e rurais do Rio Grande do Sul, Brasil. Revta Bras. Parasitol. Vet. 17:301-306.

Dijkstra T.H., Eysker M., Schares G., Conraths F.J., Wouda W. \& Barkema H.W. 2001. Dogs shed Neospora caninum oocysts after ingestion of naturally infected bovine placenta but not after ingestion of colostrums spiked with Neospora caninum tachyzoites. Int. J. Parasitol. 31:747-752.

Dubey J.P. 1988. Neosporosis: The first decate of research. Int. J. Parasitol. 29:1485-1488.

Dubey J.P. \& Lindsay D.S. 1996. A review of Neospora caninum and neosporosis. Vet. Parasitol. 67:1-57.

Dubey J.P. 2003. Neosporosis in cattle. J. Parasitol. 89:42-56.

Dubey J.P. \& Schares G. 2006. Diagnosis of bovine neosporosis. Vet. Parasitol. 140:1-34.

Dubey J.P., Schares G. \& Ortega-Mora L.M. 2007. Epidemiology and control of neosporosis and Neospora caninum. Am. Soc. Microbiol. 20:323-367.

Fanti J.H.N., Barioni G. \& Beltrame M.A.V. 2009. Soroprevalência de Neospora caninum em propriedades do município de Barra de São Francisco, Espírito Santo, Brasil. Ciênc. Anim. Bras. (Supl.1):637-641 (Anais VIII Congresso Brasileiro de Buiatria, Goiânia).

Fernandes B.C.T.M., Gennari S.M., Souza S.L.P., Carvalho J.M., Oliveira W.G. \& Cury M.C. 2004. Prevalence of anti- $N$. caninum antibodies in dogs from urban, periurban and rural áreas of the city Uberlândia, Minas Gerais, Brazil. Vet. Parasitol. 123:33-40.

Fortunaro M.C.S. 2010. Estudo Retrospectivo de Neospora caninum como causa de aborto numa exploração de bovinos de leite da região da Moita do Ribatejo. Dissertação de Mestrado, Faculdade de Medicina Veterinária, Universidade Técnica de Lisboa, Lisboa. 115p.

Gondim L.F.P., Sartor I.F., Hasegawa M. \& Yamane I. 1999. Soroprevalência of Neospora caninum in dairy cattle in Bahia, Brazil. Vet. Parasitol. 86:71-75.

Gondim L.F.P., Pinheiro A.M. \& Almeida M.A.O. 2007. Freqüência de anticorpos anti-Neospora caninum in water buffaloes (Bubalus bubalis) in Bahia State. Revta Bras. Saúde Prod. Anim. 8:92-96.

Guedes M.H.P., Guimarães A.M., Rocha C.M.B.M. \& Hirsch C. 2008. Freqüência de anticorpos anti-Neospora caninum em vacas e fetos provenientes de municípios do Sul de Minas Gerais. Revta Bras. Parasitol. Vet. 17:189-194.

Hasegawa M.Y., Sartor I.F., Canavessi A.M.O. \& Pinckney R.D. 2004. Ocorrência de anticorpos anti-Neospora caninum em bovinos de corte e em cães rurais da região de Avaré, Estado de São Paulo, Brasil. Semina, Ciênc. Agrárias 25:45-50.
Hernández J., Risco C. \& Donovan A. 2001. Association between exposure to Neospora caninum and milk production in dairy cows. J. Am. Vet. Med. Assoc. 219:632-635.

IBGE 2005. Instituto Brasileiro de Geografia e Estatística. Disponível em $<$ http://sidra.ibge.gov.br/bda/tabela/protabl.aspz=t\&0=21\&i=P>Acesso 4 abr. 2008.

Locatelli-Ditrich R., Machado Jr P.C., Fridlund-Plugger N., Richartz R.R.T.B., Montiani-Ferreira F., Patrício L.F.L., Patrício M.A.C., Joineau M.G. \& Pieppe M. 2008. Determinação e correlação de anticorpos anti-Neospora caninum em bovinos e cães do Paraná, Brasil. Revta Bras. Parasitol. Vet. 17:191-196.

Melo D.P.G., Silva A.C., Ortega-Mora L.M., Bastos A.S. \& Boaventura C.M. 2006. Prevalência de anticorpos anti-Neospora caninum em bovinos das microrregiões de Goiânia e Anápolis, Goiás, Brasil. Revta Bras. Parasitol. Vet. 15:105-109.

Munhoz A.D., Flausino W., Silva R.T., Almeida C.R.R. \& Lopes C.W.G. 2006. Distribuição de anticorpos contra Neospora caninum em vacas leiteiras dos municipios de Resende e Rio Claro, Estado do Rio de Janeiro, Brasil. Revta Bras. Parasitol. Vet. 15:101-104.

Ragozo A.M.A., Paula V.S.O., Souza S.I.P., Bergamaschi D.P. \& Gennari S.M. 2003. Ocorrência de anticorpos anti-Neospora caninum em soros bovinos procedentes de seis estados brasileiros. Revta Bras. Parasitol. Vet. 12:33-37.

Santos R.R.D., Guimarães A.M., Rocha C.M.B.M. \& Hirsch C. 2009. Freqüência de anticorpos anti-Neospora caninum em bezerras e novilhas de rebanhos leiteiros na microrregião de Lavras, Minas Gerais. Ciênc. Anim. Bras. 10:271-280.

Schares G., Barwald A., Staubach C., Ziller M., Kloss D., Schroder R., Labohm R., Drager K., Fasen W. \& Hess R.G. 2004. Potencial risk factors for bovine Neospora caninum infection in Germany are not under the control of the farmers. Parasitology 129:301-309.

Silva M.I.S., Almeida M.A.O., Mota R.A., Júnior J.W.P. \& Rabelo S.S.A. 2008. Fatores de riscos associados à infecção por Neospora caninum em matrizes bovinas leiteiras em Pernambuco. Ciênc. Anim. Bras. 9:455-461.

Teixeira W.C., Uzêda R.S., Gondim L.F.P., Silva M.I.S., Pereira H.M., Alves L.C. \& Faustino M.A.G. 2010. Prevalência de anticorpos anti-Neospora caninum (Apicomplexa: Sarcocystidae) em bovinos leiteiros de propriedades rurais em três microrregiões no estado do Maranhão. Pesq. Vet. Bras. 30:729-734.

UFAL/GEM 1994. Atlas Geográfico de Estado de Alagoas. Departamento de Geografia e Meio Ambiente, Universidade Federal de Alagoas. Ecopress, Edufal, Maceió. 44p. 